\title{
Role of camel milk in pastoral livelihoods in Kenya: contribution to household diet and income
}

\author{
Yazan Ahmed Elhadi ${ }^{1 *}$, Dickson M Nyariki ${ }^{1,2}$ and Oliver V Wasonga
}

\begin{abstract}
Pastoral livestock production in Kenya is subject to unpredictable rainfall and drought occurrences. These adverse climatic conditions have led to vulnerable and insecure pastoral livelihoods. Despite the potential to alleviate food insecurity of pastoral communities through continuous provision of milk and other products, the potential of camel milk is yet to be fully explored. This study was carried out to examine the contribution of camel milk to pastoral household food baskets and incomes. A semi-structured questionnaire was used to collect information targeting camel milk producers in Isiolo County, upper eastern region of Kenya. The findings show that camel milk contributes significantly to pastoral households. The contribution of the milk to a household food basket was found to be significantly higher $(P \leq 0.05)$ during the dry season than in the wet season. Camel milk sales contributed significantly $(P \leq 0.05)$ to household incomes throughout the year. These results show the role of camel milk as a complementary source of food and income for pastoral households. Therefore, interventions aimed at supporting pastoral households need to consider the promotion of camel milk production and marketing as an option for building pastoralists' resilience against unpredictable weather.
\end{abstract}

Keywords: Climate variability; Pastoral production; Food basket; Isiolo County

\section{Background}

In East Africa, pastoralism makes sustainable use of about $50 \%$ of the total land surface (Kratli et al. 2013). This sector further contributes significantly to the agricultural GDP of the countries within the region. For instance, in Kenya, Tanzania and Uganda, the sector accounts for $16 \%$, $45 \%$ and $32 \%$ of GDP, respectively (Behnke 2008). Pastoralism in Kenya is based on the consumption and sale of livestock and livestock products, mostly from cattle, goats, sheep and camels. The flexibility of this system permits its existence as the only efficient means of exploring available natural resources under ecologically marginal conditions, available technologies and the prevailing economy (Chikamai and Eriksen 2011).

Pastoral ecosystems in East Africa, Kenya included, are faced with many challenges, chief of them being unpredictable rainfall and drought occurrences (Elhadi et al. 2012). Climate projections for the ASALs of Kenya may include longer and more frequent dry periods

\footnotetext{
* Correspondence: yazan.a.m.elhadi@gmail.com

'Department of Land Resource Management and Agricultural Technology,

University of Nairobi, P.O. Box 29053-00625, Nairobi, Kenya

Full list of author information is available at the end of the article
}

interspersed with intense but shorter and unpredictable periods of rainfall (GoK 2007). Consequently, such weather patterns are likely to affect resource use patterns and render pastoral households vulnerable to otherwise normal variability. For example, in the Kenyan drylands, droughts have led to massive livestock losses; during the 2011 drought, mortality rates of $40 \%$ and $70 \%$ were reported for goats and sheep, and cattle, respectively (Serna 2011). These droughts have consequently weakened the resilience of pastoral production, rendering the pastoralists poor and relief dependent.

Several livelihood options have been proposed and implemented by different development agencies and institutions to enhance resilience of pastoral production systems in Kenya. These are dryland farming, apiculture, intensified investment in animal health, livestock marketing and non-land-based livelihoods (Cooper et al. 2008; Homewood et al. 2009; Elhadi et al. 2012). Additionally, more pastoralists are opting to adopt camels as a drought-tolerant species. This has mainly been driven by market demand for camel products as well as camels' abilities to tolerate climatic extremes (Zeng and Edwards 2010). Despite the abilities to support pastoral livelihoods 
under harsh climatic conditions, camels have received little attention in comparison to other livestock species in the field of scientific research and development in Kenya.

In spite of the opportunities that camel production has shown as a potential pathway to a resilient pastoral production system through milk production and rangeland improvement, few studies in Kenya have provided an indepth assessment of the role of camel milk in pastoral livelihoods. Therefore, this study was conducted to determine the contribution of camel milk to the pastoral household food basket and incomes in the drylands of Kenya, taking Isiolo County as a case study.

\section{Study area}

This study was conducted in Isiolo County, located in the upper eastern region of Kenya and covering approximately $25,000 \mathrm{~km}^{2}$. The altitude ranges from 200 to $300 \mathrm{~m}$ above sea level (Noor et al. 2012). The area borders Marsabit County to the north, Wajir and Garissa Counties to the east, Tana River and Meru Counties to the south, and Samburu and Laikipia Counties to the west. The county is classified as arid and semi-arid with low, bimodal and erratic rainfall of 350 and $600 \mathrm{~mm}$ per year (Herlocker et al. 1993). The rainy seasons are the long rains which last for three months starting from mid-March and contribute to about $40 \%$ of the total precipitation, and the short rains lasting for two to three months, usually starting in October. The county is hot throughout the year with mean annual temperatures ranging between $24^{\circ} \mathrm{C}$ and $30^{\circ} \mathrm{C}$ (Jaetzold and Schmidt 1983). The erratic rains and droughts are devastating and lead to loss of livestock and human lives (GoK 1997). The poverty level in the area, measured using 2 US dollars as the poverty line, is estimated at 70\% (Kamunyan et al. 2013). The main livelihood is pastoralism, complemented with off-farm activities such as firewood collection, charcoal burning and casual labour. The main livestock species kept are cattle, goats, sheep and camels. It is estimated that Isiolo County has about 40,300 camels mostly owned by Somali and Borana communities, with a daily milk production of about 50,000 L. The Somali camel breed is dominant in the county. About $87.5 \%$ of the produced camel milk is consumed either at the local trading centres or for subsistence at the household level (Musinga et al. 2008).

\section{Study population}

The sample population consisted of Somali and Borana pastoral households located in Isiolo Central sub-county and Kina sub-county, respectively. Communities in Isiolo County are known to keep cattle, goats and sheep as the main livestock species that constitute their mobile herds. The Somali communities are known to be traditional camel keepers and were the first to introduce the species in Isiolo County from the neighbouring Counties of Wajir and Garissa. The Borana, on the other hand, are traditional cattle keepers and just recently diversified into camel rearing as a response to frequent droughts and other calamities (Kagunyu and Wanjohi 2014). Despite the acceptance of camels as part of the mobile herd among the Borana community, the adoption rate of camel rearing is relatively low (Noor et al. 2013).

\section{Methods}

\section{Data collection}

A multistage sampling procedure was used to collect primary data from camel milk producers in the study area. The sampling procedure involved data collection at three main levels. The first level was Isiolo County, which was purposively selected based on its high share in the national camel milk production and marketing in Kenya (Noor et al. 2012). Secondly, two sub-counties within Isiolo County were sampled, based on the number of camels, the intensity of milk production and level of marketing. This is because the study ought to bring out the contribution of camel milk to pastoral households who rely to a great extent on camels and their products. In each sub-county, three sub-locations were randomly sampled to attain a sample size of 202 households, which were drawn from 20 villages. This sample size was determined using the probability proportional to size formula according to Yates and Grundy (1953).

One survey with retrospective data collection was carried out between August and October 2012 to capture the information on both last wet season (March to May) and last dry season (June to August). A semi-structured questionnaire was used to collect data such as demographic characteristics, camel milk production, camel milk marketing, income sources and amount, household food consumption, and available resources such as land and other livestock species. Focus group discussions (FGDs) and key informant interviews (KIIs) were used to complement the information gathered through the semi-structured questionnaire. Six FGDs and fifteen KIIs were conducted to clarify and give more insights on aspects of camel milk production, consumption and marketing.

\section{Data analysis}

The collected data were analysed using the Statistical Package for the Social Sciences (SPSS). Descriptive statistics were used to derive the contribution of camel milk to pastoral household food baskets and incomes during the wet and dry seasons. The results were presented in forms of percentages, frequencies, averages and standard deviations. Further, the $t$-test was done to determine if there were significant differences between the contribution of camel milk to household food basket 
and income during the wet and dry seasons. To determine the contribution of camel milk to households' food baskets, the study defined food basket as the calculated price of a set of basic foodstuff, standardised according to the percentage of expenditure on food and average household size (Øyen 1999). The basic food consumed by a household was used to arrive at different food proportions, which were then multiplied by their current market prices and their share in household food expenditure derived. Finally, these shares were converted to percentages using the total cost of the reported food basket. The items that constitute the pastoral food basket were measured in their respective standard units of measurement. Some of these items were produced and consumed at home and therefore their current market prices were used to obtain their monetary value. The contribution of camel milk to household income was directly derived from the total household income. A household was defined as 'all the people living under one roof and are subject to decisions made by the household head'. A household head is defined as one who owns and controls the major resources, makes critical decisions and provides the basic needs for the household members (Elhadi et al. 2012).

\section{Results and discussion}

\section{Household characteristics of the sampled population}

Most (80.7\%) of the households interviewed were headed by males. The majority $(73.3 \%)$ of the respondents were aged between 30 and 60 years. The respondents under 30 years made $4.0 \%$, while those over 60 years made $22.8 \%$ of the sample. The majority of the respondents (81.2\%) had not gone through formal education, while only $1.5 \%$ had attained post-secondary education. Education is an important entry point for the empowerment of pastoral communities and therefore plays a key role in sustainable development. In this context, the education level of pastoral households may have a significant importance in identifying and determining the right type of development and extension service approaches. Education influences household income, technology adoption and the socio-economic status of the family as a whole (Ejigu et al. 2009).

The average household size of the sampled population was 6 , with 3.3 and 3.4 being the average number of females and males, respectively. Household size in the pastoral context is critical as resources for herding labour. These labour resources, among other factors, directly or indirectly determine the level of assets, food and nutrition security of households and consequently the ability to cope with various natural and man-made hazards in the drylands.

All the sampled pastoral households owned the Somali camel breed. The average number of camels owned by a household was found to be 30 (Table 1). The number of lactating camels exceeded that of males, with households having an average of 21 females and 3 males, a ratio of $7: 1$. Although the lactating camels were found to dominate all the household herds, the structure of the herd varied among households, though more than $70 \%$ of the households had between $60 \%$ and $90 \%$ of their camel herds composed of lactating females.

The number of camels in the study area is relatively high compared to that in other pastoral areas in the drylands of Kenya (Noor et al. 2012). This is an indication of how important the camels are to pastoral households in the study area. Similar to other pastoral areas such as Moyale (Farah et al. 2004), the proportion of lactating camels kept is higher than that of male camels. This suggests that the main reason for keeping the camels is milk production. Generally, the lactation period of camels in the study area is reported to be between three and five seasons which accounts for about six to fifteen months, largely depending on the availability of feed and water (Musinga et al. 2008). Though camels give milk even during the dry seasons, there are peaks associated either with their physiological state (the first week after birth) or season. They produce more milk in their early part of lactation than towards the end of the period. They also produce more milk during the wet than the dry season.

\section{Contribution of camel milk to household food baskets}

The food basket of the respondents was measured in terms of the total expenditure on food items based on the average household size and the local market prices for purchased commodities. For those items which were produced and consumed at home, the equivalent of the local market prices was used to obtain their monetary value. Therefore, the contribution of each item was measured in terms of the share in the daily household expenditure. The basic pastoral household food basket in the study area consists of livestock products, grain and grain products, vegetables and sugar. The pattern of food consumption items is shown in Table 2. The average daily cost of the reported pastoral household food basket was KSh 721.11 (equivalent to 8.48 US dollars at 1:85 exchange rate), based on the average household size

Table 1 Pastoral household camel herd structure

\begin{tabular}{lcccc}
\hline Category & Minimum & Maximum & $\begin{array}{c}\text { Mean (standard } \\
\text { deviation) }\end{array}$ & $\begin{array}{c}\text { Proportion } \\
\text { (\%) }\end{array}$ \\
\hline Male camels & 1 & 40 & $3.3(4.0)$ & 10.8 \\
Lactating & 2 & 80 & $20.9(15.7)$ & 68.3 \\
camels & & & & \\
Calves & 2 & 40 & $6.4(5.5)$ & 20.9 \\
Total & 5 & 160 & 26.7 & 100 \\
\hline
\end{tabular}


Table 2 Pastoral household food basket per day

\begin{tabular}{|c|c|c|c|c|c|}
\hline Foodstuff & $\begin{array}{l}\text { Proportion of } \\
\text { respondents (\%) }\end{array}$ & $\begin{array}{l}\text { Daily consumption (kg or L) } \\
\text { per average household }\end{array}$ & $\begin{array}{c}\text { Average price in } \\
\mathrm{KSh} / \mathrm{kg} / \mathrm{L}\end{array}$ & Expenditure (KSh) & $\begin{array}{c}\text { Proportion of total } \\
\text { expenditure (\%) }\end{array}$ \\
\hline Cow milk & 87.6 & 1.08 & 49.70 & 53.43 & 7.41 \\
\hline Camel milk & 60.9 & 2.29 & 64.30 & 147.25 & 20.42 \\
\hline Cow meat & 30.2 & 0.38 & 280 & 105.00 & 14.56 \\
\hline Goat meat & 32.2 & 0.38 & 333.30 & 126.65 & 17.56 \\
\hline Camel meat & 30.7 & 0.59 & 300.00 & 177.00 & 24.55 \\
\hline Maize meal & 74.8 & 0.47 & 68.80 & 32.34 & 4.48 \\
\hline Vegetables & 65.8 & 0.32 & 19.00 & 6.08 & 0.84 \\
\hline Oil & 89.1 & 0.12 & 129.90 & 14.94 & 2.07 \\
\hline Rice & 59.4 & 0.12 & 76.70 & 9.20 & 1.28 \\
\hline Spaghetti & 51.5 & 0.14 & 75.80 & 10.23 & 1.42 \\
\hline Sugar & 100.0 & 0.34 & 116.40 & 38.99 & 5.41 \\
\hline Total & & & & 721.11 & 100.00 \\
\hline
\end{tabular}

Note: The expenditure is calculated based on the average local market prices in 2012.

of the sampled population. This was mostly spent on livestock-related foodstuffs, namely meat and milk items.

The proportion of households who consumed each reported item was varied. For example, while sugar, oil and cow milk were consumed by almost the entire sampled population, the level of consumption was $30.2 \%, 32.2 \%$ and $30.7 \%$ for cow, goat and camel meat, respectively. Camel milk was consumed by $60.9 \%$ of the sampled population. This therefore shows that milk is one of the most important contributors to the pastoral household food basket. Similarly, the expenditure on the reported foodstuffs varied among the interviewed households. Most households tended to spend more on essential and relatively cheap foods such as milk.

Livestock products contributed $84.5 \%$ of the pastoral household food basket as measured in terms of daily household expenditure. Camel meat had the highest contribution (24.6\%) followed by camel milk (20.4\%). Goat meat, cow meat, sugar and maize meal also contributed $17.6 \%, 14.7 \%, 5.4 \%$ and $4.5 \%$, respectively. Oil and vegetables had the least contribution to the food basket of the sampled population.

Table 3 presents the pastoral household food basket during the wet and dry seasons. The average daily expenditure on the pastoral household food basket during the wet season was KSh 763, and during the dry season, it was KSh 674 (equivalent to 9 and 7.9 US dollars, respectively).

The quantities of different types of foodstuff consumed varied between the wet and dry seasons. During the wet season, the average quantities of milk consumed per average household was 1.6 and $2 \mathrm{~L}$ for cow milk and camel milk, respectively. The average quantity of meat products also varied in the wet season, with $0.5 \mathrm{~kg}$ of cow meat, $0.4 \mathrm{~kg}$ of goat meat and $0.6 \mathrm{~kg}$ of camel meat.

During the dry season, households reported a decrease in cow milk consumption $(0.5 \mathrm{~L})$ and an increase in camel milk consumption $(2.5 \mathrm{~L})$. Meat products showed a decrease in the quantity consumed during the dry season, with $0.2,0.3$ and $0.5 \mathrm{~kg}$ for cow, goat and camel meat, respectively. The average quantities of nonlivestock products such as maize meal, vegetables, oil, rice, spaghetti and sugar remained the same during the wet and dry seasons.

Livestock products had the highest overall contribution to household daily expenditure in both the wet and dry seasons, with $61.1 \%$ during the wet season and $88.2 \%$ during the dry season. During the wet season, camel meat had the highest contribution (23.4\%) followed by cow meat (18.8\%) and goat meat (17.4\%). Milk products had the least contribution among livestock-related products, with $14.4 \%$ and $10.4 \%$ for camel milk and cow milk, respectively. Rice, spaghetti and vegetables had the least contribution to the household food basket during the wet season, at $1.4 \%, 1.4 \%$ and $0.8 \%$, respectively.

During the dry season, the contribution of different foodstuff to the pastoral household food basket changed dramatically, with a general trend of increasing the contribution of livestock products and decreasing that of non-livestock products. This increase is mostly associated with an increase in the relative prices of livestock products during the dry season, as a direct result of less forage and water, which constitute the main input for any given livestock production. Camel milk had the highest contribution (28.2\%) followed by camel meat 
Table 3 Pastoral household food basket during wet and dry seasons

\begin{tabular}{|c|c|c|c|c|c|c|c|c|c|}
\hline \multirow[t]{2}{*}{ Foodstuff } & \multicolumn{4}{|c|}{ Wet season } & \multicolumn{4}{|c|}{ Dry season } & \multirow[t]{2}{*}{ Chi-square } \\
\hline & $\begin{array}{l}\text { Daily } \\
\text { consumption } \\
\text { (kg or } \mathrm{L})\end{array}$ & $\begin{array}{l}\text { Average } \\
\text { prices/kg } \\
\text { or } L\end{array}$ & $\begin{array}{l}\text { Expenditure } \\
\text { (KSh) }\end{array}$ & $\begin{array}{c}\text { Proportion } \\
\text { of total } \\
\text { expenditure (\%) }\end{array}$ & $\begin{array}{c}\text { Daily } \\
\text { consumption } \\
\text { (kg or } \mathrm{L})\end{array}$ & $\begin{array}{c}\text { Average } \\
\text { prices } / \mathrm{kg} \\
\text { or } \mathrm{L}\end{array}$ & $\begin{array}{l}\text { Expenditure } \\
\text { (KSh) }\end{array}$ & $\begin{array}{c}\text { Proportion } \\
\text { of total } \\
\text { expenditure (\%) }\end{array}$ & \\
\hline Cow milk & 1.63 & 48.69 & 79.36 & 10.40 & 0.52 & 50.71 & 26.37 & 3.91 & 2.278 \\
\hline Camel milk & 2.04 & 53.80 & 109.75 & 14.38 & 2.54 & 74.80 & 189.99 & 28.19 & $4.887^{* *}$ \\
\hline Cow meat & 0.54 & 266.00 & 143.64 & 18.83 & 0.21 & 294.00 & 61.74 & 9.16 & 3.071 \\
\hline Goat meat & 0.43 & 308.25 & 132.55 & 17.37 & 0.33 & 358.35 & 118.26 & 17.55 & 0.028 \\
\hline Camel meat & 0.64 & 278.50 & 178.24 & 23.36 & 0.54 & 321.50 & 173.61 & 25.76 & 0.053 \\
\hline Maize meal & 0.52 & 70.20 & 36.50 & 4.78 & 0.42 & 67.40 & 28.31 & 4.20 & 0.019 \\
\hline Vegetables & 0.30 & 21.33 & 6.40 & 0.84 & 0.34 & 16.67 & 5.67 & 0.84 & 0.630 \\
\hline Oil & 0.13 & 122.80 & 15.96 & 2.09 & 0.10 & 137.00 & 13.70 & 2.03 & 0.202 \\
\hline Rice & 0.13 & 81.00 & 10.53 & 1.38 & 0.11 & 72.40 & 7.96 & 1.18 & 0.249 \\
\hline Spaghetti & 0.14 & 75.30 & 10.54 & 1.38 & 0.13 & 76.30 & 9.92 & 1.47 & 0.283 \\
\hline Sugar & 0.34 & 116.20 & 39.51 & 5.18 & 0.33 & 116.60 & 38.48 & 5.71 & 0.024 \\
\hline Total & & & 762.99 & 100.00 & & & 674.00 & 100.00 & \\
\hline
\end{tabular}

**Significant at 5\%. Expenditure is calculated based on the average local market prices in 2012.

(25.8\%) and goat meat (17.6\%). Cow meat and milk contributed $9.2 \%$ and $3.9 \%$, respectively. The contribution of maize meal was $4.2 \%$, that of sugar $5.7 \%$, and that of rice $1.2 \%$ of the food basket. The contribution of camel milk increased significantly $(P \leq 0.05)$ during the dry season.

The decrease in the average daily expenditure during the dry season is an indication that pastoral households have less to spend on food during the dry spells and therefore consume less. This is possibly a result of less income generated from sales of animals (mostly small stock) and other livelihood activities. For instance, the consumption of non-livestock products drops during the dry season by about $75 \%$. However, the overall food consumption, measured in terms of average quantities consumed per average household size, only drops by about $20 \%$; this is because the contribution of livestock products increases during the dry season. Camel milk has an important contribution to the household food basket in the dry season, and thus without the milk, food consumption would drop by about 30\% during the dry season. On the other hand, the expenditure on nonlivestock products (mostly purchased food items) remains almost identical in the dry season. However, the high prices of livestock products during this period force pastoral households to buy and consume less food using the same amount of money. Basically, products from household livestock enable households to compensate for the higher prices of non-livestock foodstuff in the dry season that would otherwise cut their consumption by about $75 \%$. The high prices in the dry season are mostly associated with the general scarcity of forage and water. This leads, for instance, to less milk production and thus higher demand, which pushes prices upwards. For the majority of pastoralists in the study area, preference is given to livestock product offtake rather than consumption.

The variation in the contribution and availability of food items to pastoral household food baskets in relation to seasons can be explained by the fact that the availability of food in pastoral areas is highly affected by seasonal fluctuations. This mostly subjects pastoralists to seasonal and long-term shifts in terms of trade between the main local commodities of live animals, dairy products and food grains. This might result in a food supply gap, particularly during prolonged dry seasons and drought, whereby the animals fail to produce enough products for domestic use as well as for exchange. Thus, food insecurity and malnutrition become inevitable. Our study found that during the dry season, camel milk contributed significantly to the household food basket compared to the wet season. This confirms the study's hypothesis that camel milk indeed contributes significantly to the household food baskets in the drylands of Kenya where camels are commonly raised, playing a vital role in the pastoral diet, particularly during the dry season. This finding is similar to that of Emukule et al. (2011) who reported that camel milk contributed more than $50 \%$ of the nutrient intake of the pastoralists in northern Kenya. This can be further explained by the fact that camels are least affected by dry conditions, compared to other livestock species in the same pastoral production system.

Under prolonged dry season and drought conditions, the productivity and performance of most animals are significantly affected by the lack of water and feed resources. Most of the time, cattle are most adversely affected compared to camels, although cattle are the main livestock species in most pastoral production systems in 


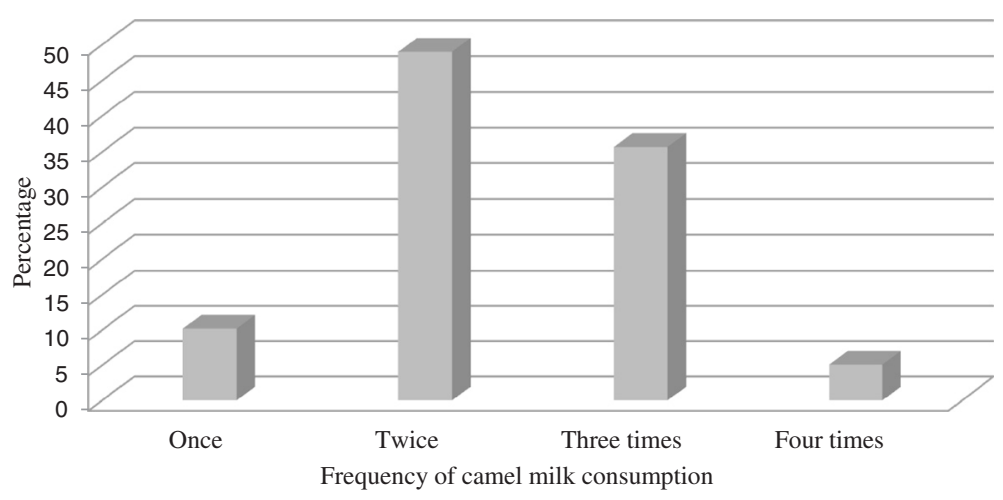

Figure 1 Frequency of camel milk consumption in the study area.

Kenya. This is evident from many studies that have compared the effect of drought and prolonged dry season across all livestock species that constitute the pastoral production system (Faye et al. 2012; Schwartz et al. 1992; Farah et al. 2004; Mehari et al. 2007; Serna 2011). The camel has the ability to withstand harsh climatic conditions with the ability to cope with shortage of water and feed during prolonged dry seasons. Despite these adverse conditions, camels have the ability to supply pastoral households with milk during such periods.

Hunger among pastoral households in the study area is mostly associated with the dry season. This results from different interrelated factors, including the deteriorated condition of livestock due to scarcity of water and pasture (Witsenburg and Adano 2009). During the dry season, milk production, which forms an essential component of the pastoral household diet in the wet seasons, is drastically reduced (Ilatsia et al. 2007). It has been observed, especially among pastoralists, that when access to milk is reduced, acute malnutrition rates tend to increase, but decline when access to milk is increased (Sadler et al. 2009).

The contribution of camel milk to household food baskets and thus food security, particularly in the arid and semi-arid areas of Kenya, is now evident. It is therefore critical to examine the patterns of camel milk consumption among pastoral households. This information is particularly useful for key stakeholders involved in the production, processing and marketing of camel milk. Figure 1 shows the frequency and forms of camel milk usage at the household level across the sampled population.

Across the sampled population, the most common frequency of camel milk consumption was twice per day (49\%) followed by three times a day (35.7\%). Camel milk is traditionally consumed raw by pastoralists. Most of the households consumed the milk when fresh, even though there were some variations among households. For instance, the majority of the households consume camel milk either in tea or with grain. Similar results were reported by Sato (1997) who observed that most communities in Isiolo District consumed camel milk in raw and fresh form, with more than $50 \%$ consuming it twice a day. Akweya et al. (2012) reported that more that $75 \%$ of the households in Garissa District use camel milk in their raw form and that more than $60 \%$ consumed the milk twice a day. The frequency and forms of camel milk consumption suggest that it plays an essential role in pastoral household daily nutritional intake. This finding, coupled with the significant contribution of camel milk

Table 4 Pastoral household livelihood activities in the study area

\begin{tabular}{|c|c|c|c|c|c|c|}
\hline \multirow[t]{2}{*}{ Livelihood activity } & \multicolumn{2}{|c|}{ Average for wet and dry seasons } & \multicolumn{2}{|c|}{ Wet season (March May) } & \multicolumn{2}{|c|}{ Dry season (July-August) } \\
\hline & Income (KSh) & $\%$ of total income & Income (KSh) & $\%$ of total income & Income (KSh) & $\%$ of total income \\
\hline Sales of camel milk $(N=197)$ & $27,376.55^{*}$ & 38.70 & $33,578.20$ & 40.85 & $21,174.90^{*}$ & 35.70 \\
\hline Sales of livestock $(N=57)$ & $19,537.20$ & 27.62 & $26,333.30$ & 32.04 & $12,741.10$ & 21.50 \\
\hline Sales of cow milk $(N=37)$ & $1,132.55$ & 1.60 & $1,209.30$ & 1.47 & $1,055.80$ & 1.80 \\
\hline Sales of charcoal $(N=14)$ & $5,057.50$ & 7.15 & $3,536.40$ & 4.30 & $6,578.60$ & 11.10 \\
\hline Petty trade $(N=39)$ & $10,178.20$ & 14.39 & $10,076.90$ & 12.26 & $10,279.50$ & 17.30 \\
\hline Casual labour $(N=11)$ & $5,227.30$ & 7.39 & $5,227.30$ & 6.36 & $5,227.30$ & 8.80 \\
\hline Formal employment $(N=20)$ & $2,230.00$ & 3.15 & $2,230.00$ & 2.71 & $2,230.00$ & 3.80 \\
\hline Total & $70,739.3$ & 100.00 & $82,191.40$ & 100.00 & $59,287.20$ & 100.00 \\
\hline
\end{tabular}

$N$, proportion of the sampled population. *Significant at $5 \%$, two way $t$-test. 
to pastoral household food baskets, shows that camel milk has the potential of providing a reliable input to food security and a resilient pastoral production system in the drylands of Kenya.

\section{Contribution of camel milk to household income}

Livestock-related activities collectively emerged to be the major contributor to household income, among $67.9 \%$ of the respondents. Sale of camel milk was the highest (38.7\%) contributor followed by sale of live animals (27.6\%) and petty trade (14.4\%). The contribution of casual labour, sale of charcoal and salary from formal employment was $7.4 \%, 7.2 \%$ and $3.2 \%$, respectively. Sale of cow milk had the least contribution with $1.6 \%$ (Table 4).

Camel milk has a significant contribution $(P \leq 0.05)$ to household income during both the wet and dry seasons, by $40.9 \%$ and $35.7 \%$, respectively. This was followed by live animals, mostly goats and sheep, in both the wet season (32\%) and the dry season (21.5\%). Petty trade was the third contributor in both seasons. Other activities include sale of charcoal, casual labour and formal employment.

The dominant contribution of livestock-related livelihood activities to household income across seasons implies that pastoral households continue to produce different livestock products throughout the year despite water stress and pasture scarcity, which are the main inputs to the pastoral production system. This finding is contrary to that of Elhadi et al. (2012) who observed that during the dry season in the semi-arid areas of Baringo District of Kenya, the contribution of livestock to total household income is dramatically reduced compared to the wet season. The Baringo households engage more in off-farm activities. This contrast may be explained by the fact that in Isiolo County, household herds are mainly composed of camels, with a few small stock and cattle. Such a herd species composition has the ability to produce milk throughout the year, therefore contributing significantly to pastoral household income, irrespective of the season. This is particularly because camel milk production is less affected by seasonal fluctuations and, unlike other livestock species, output is less suppressed by lack of water and pasture.

In northern Kenya, the important roles of camel milk have long been recognised, since camel milk sales have been shown to exceed other income sources (Noor et al. 2012). Thus, sale of camel milk is not only a way of disposing of surpluses during the wet season, but also an integral process through which households obtain the necessary means for purchasing other essential food items, especially during the dry season. This is similar to the finding of Anderson et al. (2012) in Kenya, who reported an increase in camel milk sales during the dry season compared to the wet season. Further, it was observed during data collection that most camel milk sale activities were managed by women. This has a significant advantage within the pastoral family, since the income obtained will mostly be spent on food-related items, whereas if this income was managed by men, their expenditures may be concentrated on other nonfood-related items. A similar observation was made by Fratkin and Smith (1995), who reported that any increase in women's income may have a beneficial effect on the nutrition and well-being of their families.

The high contribution of camel milk to household income, compared to off-farm activities, can further be explained by the behaviour of households who live near market centres. Most of these households engage in milk trading and are, therefore, less dependent on off-farm activities. The close proximity of households to market centres leads them to selling available animal products rather than searching for other off-farm activities. As reported by Seifu (2011), living near a town has encouraged pastoralists to participate more in the camel milk value chain; in most camel-owning households, camel milk sales dominate in their total cash income. Although most traditional camel keepers are rearing camels for subsistence, many non-traditional camel keepers are moving into the camel milk business as it offers an opportunity for sustainable income throughout the year. This indicates the potential of commoditisation of camel milk as a promising pathway out of poverty and food insecurity in the drylands.

\section{Conclusion}

The contribution of camel milk to household food intake is significant during the dry season. Similarly, camel milk contributes significantly to pastoral household income during both the wet and dry seasons. In the context of recurrent drought, and diminishing grazing and water resources, rearing camels can therefore provide a viable supplement to sustainable pastoral household livelihood. Based on these findings, there is a need to invest in the camel milk subsector by creating an enabling environment to enhance milk production and marketing. Furthermore, interventions that target the improvement of pastoral livelihoods should consider the promotion of camel milk production as a suitable strategy for building pastoral household resilience.

\section{Competing interests}

The authors declare that there is no conflict of interest relating to any part of this work.

\section{Authors' contribution}

YAE collected field data, generated results and structured the manuscript. DMN and OWW provided technical guidance on methodology, data processing and article structure.

\section{Author details}

'Department of Land Resource Management and Agricultural Technology, University of Nairobi, P.O. Box 29053-00625, Nairobi, Kenya. ${ }^{2}$ South Eastern Kenya University, P.O. Box 170-90200, Kitui, Kenya. 
Received: 19 June 2014 Accepted: 29 March 2015

Published online: 20 April 2015

\section{References}

Akweya, A, G Gitao, and W Okoth. 2012. The acceptability of camel milk and milk products from north eastern province in some urban areas of Kenya. African Journal of Food Science 6: 465-473. doi:10.5897/AJFS10.061.

Anderson, D, H Elliott, H Kochore, and E Lochery. 2012. Camel herders, middle women, and urban milk bars: The commodification of camel milk in Kenya. Journal of Eastern African Studies 6: 383-404. doi:10.1080/17531055.2012.696886.

Behnke, RH. 2008. The economic contribution of pastoralism: Case studies from the Horn of Africa and southern Africa. Nomadic People 12: 45-79. doi:10.3167/np.2008.120104.

Chikamai, N, and S Eriksen. 2011. Gums and resins: The potential for supporting sustainable adaptation in Kenya's drylands. Climate and Development 3: 59-70. doi:10.3763/cdev.2010.0064.

Cooper, P, J Dimes, K Rao, B Shapiro, B Shiferaw, and S Twomlow. 2008. Coping better with current climatic variability in the rain-fed farming systems of sub-Saharan Africa: An essential first step in adapting to future climate change. Agriculture, Ecosystems and Environment 126: 24-35. doi:10.1016/j.agee.2008.01.007.

Ejigu, K, T Gebey, and T Preston. 2009. Constraints and prospects for apiculture research and development in Amhara region, Ethiopia. Livestock Research for Rural Development 21. http://rrd.cipav.org.co//rrd21/10/ejig21172.htm. Accessed 17 January 2013

Elhadi, Y, D Nyariki, V Wasonga, and W Ekaya. 2012. Factors influencing transient poverty among agro-pastoralists in semi-arid areas of Kenya. African Crop Science Journal 20: 113-122.

Emukule, J, M Ngigi, and A Guliye. 2011. Analysis of socio-economic factors influencing willingness to pay for camel milk in Nakuru District, Kenya. Livestock Research for Rural Development 23. http://www.Irrd.org/Irrd23/1/ emuk23016.htm. Accessed 18 May 2013.

Farah, K, D Nyariki, R Ngugi, I Noor, and A Guliye. 2004. The Somali and the camel: Ecology, management and economics. Anthropologist 6: 45-55.

Faye, B, M Chaibou, and G Vias. 2012. Integrated impact of climate change and socioeconomic development on the evolution of camel farming systems. British Journal of Environment and Climate Change 2:227-244. doi:10.9734/BJECC/2012/1548

Fratkin, E, and K Smith. 1995. Women's changing economic roles with pastoral sedentarization: Varying strategies in alternate Rendille communities. Human Ecology 23: 433-454. doi:10.1007/BF01190131.

GoK. 2007. National Draft Policy on the sustainable development of ASALs. Nairobi, Kenya: Government Printer. Available in the archive of Kenya Government.

GoK (Government of Kenya). 1997. Isiolo District development plan for 1997-2001. Nairobi, Kenya: Government Printer. Available in the archive of Isiolo County Government.

Herlocker, D, S Shaaban, and S Wilkes. 1993. Range management handbook of Kenya. Volume II, Isiolo District. Nairobi, Kenya: Ministry of Agriculture, Livestock Development and Marketing.

Homewood, K, P Kristjanson, and P Trench. 2009. Staying Maasai? Livelihoods, conservation and development in East African rangelands. New York, United State of America: Springer.

Ilatsia, E, T Muasya, W Muhuyi, and A Kahi. 2007. Milk production and reproductive performance of Sahiwal cattle in semi-arid Kenya. Tropical Science 47: 120-127. doi:10.1002/ts.205.

Jaetzold, R, and H Schmidt. 1983. Farm management handbook of Kenya: Natural conditions and farm management information. Nairobi, Kenya: Ministry of Agriculture.

Kagunyu, AW, and J Wanjohi. 2014. Camel rearing replacing cattle production among the Borana community in Isiolo County of Northern Kenya, as climate variability bites. Pastoralism 4: 1-5. doi:10.1186/s13570-014-0013-6.

Kamunyan, C, G Cheserek, M Kiptui, and E Arusei. 2013. Causes and effects of post-election violence on agricultural production in Kesses Division, Uasin Gishu County, Kenya. Journal of Emerging Trends in Economics and Management Sciences 4: 62-70. doi:10520/EJC132589.
Kratli, S, C Huelsebusch, S Brooks, and B Kaufmann. 2013. Pastoralism: A critical asset for food security under global climate change. Animal Frontiers 3: 42-50. doi:10.2527/af.2013-0007.

Mehari, Y, Z Mekuriaw and G Gebru. 2007. Potentials of camel production in Babilie and Kebribeyah Woredas of the Jijiga Zone, Somali Region, Ethiopia. Livestock Research for Rural Development, 19. http://rrd.cipav.org.co//rrd19/ 4/meha19058.htm. Accessed 13 March 2013.

Musinga M, D Kimenye and P Kivolonz. 2008. The camel milk industry in Kenya. Results of a study commissioned by SNV to explore the potential of camel milk from Isiolo District to access sustainable formal markets. SNV world, The Hage, Netherlands: Nairobi, Kenya. http://www.snwworld.org/en/download/ publications/camel_milk_industry_in_kenya.pdf. Accessed 24 January 2013.

Noor, IM, A Guliye, M Tariq, and B Bebe. 2013. Assessment of camel and camel milk marketing practices in an emerging peri-urban production system in Isiolo County, Kenya. Pastoralism 3: 1-8. doi:10.1186/2041-7136-3-28.

Noor, I, B Bebe, and A Guliye. 2012. Analysis of an emerging peri-urban camel production in Isiolo County, northern Kenya. Journal of Camelid Science 5: 41-61.

Øyen, E. 1999. The politics of poverty reduction. International Social Science Journal 51(162): 459-465.

Sadler, K, C Kerven, M Calo, M Manske, and A Catley. 2009. Milk matters. A literature review of pastoralist nutrition and programming responses. Addis Ababa, Ethiopia: Feinstein International Centre, Tufts University and Save the Children. http://www.alnap.org/resource/10027. Accessed 16 May 2013.

Sato, S. 1997. How the East African pastoral nomads, especially the Rendille, respond to the encroaching market economy. African Study Monographs 18: 121-135.

Schwartz, H, M Dioli, R Stimmelmayr, and M Walsh. 1992. The one-humped camel (Camelus dromedarius) in eastern Africa. A pictorial guide to diseases, health care and management. Amsterdam, Germany: Verlag Josef Margraf.

Seifu, E. 2011. Analysis on the contributions of and constraints to camel production in Shinile and Jijiga zones, eastern Ethiopia. Journal of Agriculture and Environment for International Development 103: 213-224. doi:10.12895/jaeid.20093.33.

Serna, J. 2011. Drought assessment in north-eastern Kenya (Wajir East, South and Mandera). Save the children, publication. http://www.disasterriskreduction.net. Accessed 16 May 2013.

Witsenburg, K, and W Adano. 2009. Of rain and raids: Violent livestock raiding in northern Kenya. Civil Wars 11: 514-538. doi:10.1080/13698240903403915.

Yates, F, and P Grundy. 1953. Selection without replacement from within strata with probability proportional to size. Journal of the Royal Statistical Society. Series B (Methodological) 15: 253-261.

Zeng, B, and G Edwards. 2010. Perceptions of pastoralists and conservation reserve managers on managing feral camels and their impacts. Rangeland Journal 32: 63-72. doi:10.1071/RJ09036.

\section{Submit your manuscript to a SpringerOpen ${ }^{\circ}$ journal and benefit from:}

- Convenient online submission

- Rigorous peer review

- Immediate publication on acceptance

- Open access: articles freely available online

- High visibility within the field

- Retaining the copyright to your article

Submit your next manuscript at $>$ springeropen.com 